\title{
DIFFERENTIATED INSTRUCTION IN PRIMARY SCHOOLS: IMPLEMENTATION AND CHALLENGES IN INDONESIA
}

\author{
Muhamad Nanang Suprayogi \\ Department of Educational Studies, Ghent University, Gent, Belgium \\ Department of Psychology, Bina Nusantara University, Jakarta, Indonesia \\ Tel: +32 9264 8643, (muhamadnanang.suprayogi@ugent.be) \\ Martin Valcke \\ Department of Educational Studies, Ghent University, Gent, Belgium \\ Tel: +32 9264 8675, (martin.valcke@ugent.be)
}

\begin{abstract}
The paper identifies the level and nature of differentiated instruction (DI) implementation in Indonesian primary schools. Teachers reported their level of DI adoption and reacted to five vignettes reflecting key dimensions of DI. Research data revealed overall DI implementation is significantly below the mastery learning benchmark (80\%). Nevertheless, teachers feel they are able to cope with student diversity and have basic ideas about DI implementation. Research implications point at educational policies to invest in initial teacher training and professional development, next to a need for parent involvement. Future research could centre on studying actual teacher behavior in classrooms, next to experimenting with particular DI-strategies.
\end{abstract}

Keywords: Differentiated instruction, teaching strategies, primary school, teacher, Indonesia

\section{Introduction}

International performance indicator studies point at the critical status of Indonesian education. The Learning Curve report (TLC, 2014) -developing the index of cognitive skills and educational attainment- ranks Indonesia 40 out of 40 countries. The Program for International Student Assessment (PISA) ranks Indonesia 64 out of 65 countries (PISA, 2012). These international performance indicator studies underpin the need for Indonesia to improve the educational quality.

Focusing on the Indonesian education context, Sofo, Fitzgerald, and Jawas (2012), describe three educational problems: (1) managerial shortcomings; (2) too frequent curriculum changes, and (3) the low quality of teaching. In relation to the latter, research from Zulfikar (2009) identified two priorities to tackle: (1) teachers adopt too much a teacher-centred classroom pedagogy; (2) they emphasize rote learning. Zulfikar suggests establishing professional communities of learners and the development of advanced pedagogical and pedagogical content knowledge (Zulfikar, 2009). The study of Maulana, Opdenakker, den Brok, and Bosker (2011) also suggest the teacher professional development in Indonesia. In the context of the latter, authors propose the adoption of Differentiated Instruction (DI) (Fogarty \& Pete, 2011; Tomlinson \& Imbeau, 2010). DI approaches are geared to cater for diverse characteristics of students and pushes teachers to apply various teaching strategies and invoke a broader range of learning activities. 
Following the prevailing challenges described in the Indonesian context, the present study centres on the level and the nature of current DI-adoption by primary school teachers. The results of this study are expected to define benchmarking information to inspire macrolevel and school-level policies; especially related to teacher professional development.

\section{Theoretical background}

\subsection{Differentiated instruction and its impact}

Differentiated instruction (DI) is a teaching philosophy and practice that places students at the centre of educational decisions. DI starts from the premise that learners are inherently different and learn in different ways (Fogarty \& Pete, 2011; Tomlinson, 1995). Teachers, adopting DI, recognize that students differ in their prior knowledge and prior experiences, their readiness, language, culture, learning preferences, and interest. DI stresses that a single teaching style will not accommodate every student, especially when the teaching style is not matched with a student's learning style (Levine, 2002). Therefore, DI pushes teachers to vary learning activities, content demands, modes of assessment, and the classroom environment to meet the needs and support the growth of each child (Thousand, Villa, \& Nevin, 2007).

Plenty of research is available about DI and how it affects the learning processes. DI implementation has a positive impact on student achievement. For instance, research by Tulbure (2011) concluded that students in a DI setting achieved higher academic scores. Beloshitskii and Dushkin (2005) reported the use of differentiated sets of learning tasks resulted in better overall performance as compared to a traditional style of teaching. Another study by Wilujeng (2012) stressed how DI adoption maximizes students' individual potential.

Research -set up in the context of specific school subjects- reiterates the positive influence of DI. Firmender, Reis, and Sweeny (2013) showed that DI helped to achieve significant progress in reading for all learners. Tobin and McInnes (2008) concluded DI helped the development of student understand literacy. DI also resulted in significantly greater mathematics achievement (Chamberlin \& Power, 2010). Additionally Grimes and Stevens (2009) reported that DI increased students' desire to do well in math and students gained confidence in their mathematical abilities.

Next to an impact on achievement, research also points at the positive impact on critical student variables. Johnsen (2003) showed how DI resulted in more engaged and interested learners. Additionally, DI was found to result in larger student persistence level (Tomlinson, 1995). It is also reported that it enhances student self-confidence and engagement, helps students to become more self-directed and become more metacognitive aware learners (McQuarrie \& McRae, 2010).

\subsection{Dimensions of differentiated instruction}

Differentiated instruction is a multi-dimensional concept. Fox and Hoffman (2011) list several alternative concepts; such as differentiated assessment, inclusion, student-centred. 
Other conceptualisations are individualized instruction (Hattie, 2009), adaptive instruction, personalized learning (Waxman, Alford, \& Brown, 2013), response to intervention (Dalhouse et al., 2009 ; Fox \& Hoffman, 2011). All concepts put the student as the centre of educational decisions.

Since DI is a multi-dimensional concept, different authors proposed divergent lists of components or dimensions of DI. We summarize this in the table below and look for shared dimensions (integration column).

Table 1: Inventory of DI dimensions as reported in the literature and an integrated perspective

\begin{tabular}{|c|c|c|c|c|c|}
\hline $\begin{array}{l}\text { Moore } \\
(2005) \\
\end{array}$ & $\begin{array}{l}\text { Tomlinson and } \\
\text { Imbeau (2010) }\end{array}$ & $\begin{array}{l}\text { Fogarty and Pete } \\
(2011)\end{array}$ & $\begin{array}{l}\text { Whipple } \\
(2012)\end{array}$ & $\begin{array}{l}\text { Smit and Humpert } \\
(2012)\end{array}$ & Integration \\
\hline $\begin{array}{l}\text { Differences } \\
\text { in content }\end{array}$ & $\begin{array}{l}\text { Differences in } \\
\text { learning profiles }\end{array}$ & $\begin{array}{l}\text { Provide choice to } \\
\text { learners }\end{array}$ & $\begin{array}{l}\text { Differences } \\
\text { in lesson } \\
\text { planning }\end{array}$ & $\begin{array}{l}\text { Differences in } \\
\text { Attitude }\end{array}$ & $\begin{array}{l}\text { Coping with } \\
\text { student diversity }\end{array}$ \\
\hline $\begin{array}{l}\text { Differences } \\
\text { in Process }\end{array}$ & $\begin{array}{l}\text { Differences in } \\
\text { readiness }\end{array}$ & $\begin{array}{l}\text { Change the } \\
\text { content, process } \\
\text { and product }\end{array}$ & $\begin{array}{l}\text { Differences } \\
\text { in content }\end{array}$ & $\begin{array}{l}\text { Differences in } \\
\text { Content }\end{array}$ & $\begin{array}{l}\text { Adopting specific } \\
\text { teaching strategy }\end{array}$ \\
\hline $\begin{array}{l}\text { Differences } \\
\text { in product }\end{array}$ & $\begin{array}{l}\text { Differences in } \\
\text { content }\end{array}$ & $\begin{array}{l}\text { Challenge the } \\
\text { emotions, } \\
\text { attention, } \\
\text { memory of } \\
\text { different learners }\end{array}$ & $\begin{array}{l}\text { Differences } \\
\text { in processes }\end{array}$ & $\begin{array}{l}\text { Differences in } \\
\text { Process/product }\end{array}$ & $\begin{array}{l}\text { Invoking a } \\
\text { variety in } \\
\text { learning activity }\end{array}$ \\
\hline \multirow[t]{3}{*}{$\begin{array}{l}\text { Differences } \\
\text { in Learning } \\
\text { Environment }\end{array}$} & $\begin{array}{l}\text { Differences in } \\
\text { process }\end{array}$ & & $\begin{array}{l}\text { Differences } \\
\text { in student } \\
\text { interests }\end{array}$ & $\begin{array}{l}\text { Differences in } \\
\text { Communication/c } \\
\text { ollaboration } \\
\text { /coaching }\end{array}$ & $\begin{array}{l}\text { Monitoring } \\
\text { individual } \\
\text { student needs }\end{array}$ \\
\hline & $\begin{array}{l}\text { Differences in } \\
\text { affect }\end{array}$ & & $\begin{array}{l}\text { Differences } \\
\text { in assessment }\end{array}$ & $\begin{array}{l}\text { Differences in } \\
\text { Formative } \\
\text { assessment }\end{array}$ & $\begin{array}{l}\text { Pursuing optimal } \\
\text { learning } \\
\text { outcomes }\end{array}$ \\
\hline & $\begin{array}{l}\text { Differences in } \\
\text { interests } \\
\text { Differences in } \\
\text { products }\end{array}$ & & $\begin{array}{l}\text { Differences } \\
\text { in products }\end{array}$ & & \\
\hline
\end{tabular}

Building on the table, five dimensions can be considered as shared by most authors. We build on these five dimensions to present a DI working definition: Differentiated instruction is an instructional approach that accommodates the diversity of students by (1) coping with student diversity; (2) adopting specific teaching strategy; (3) invoking a variety in learning activity; (4) monitoring individual student needs, and (5) pursuing optimal learning outcomes.

First, coping with student diversity, in a typical class, there is diversity in students in term of their readiness, ability, learning style, economic status, etc. Teachers cannot neglect this diversity and should adopt specific organisational measures; e.g., through varying grouping, varying time-to-task, investing more or less time as a teacher (Heacox, 2012). Coping can be realized by ability grouping, presenting alternatives that fit different learning styles, and building on different life situations of learners. A typical example of the latter is not giving homework to pupils when there is weak parental support. Teachers should realize that all students are inherently different and learn in a different way (Fogarty \& Pete, 2011; Tomlinson, 1995). 
Second, adopting specific teaching strategy, the key is that teaching strategies should "fit" student characteristics. Therefore, they should be varied, aim at the active involvement of learners, build on student initiative, and focus on peer learning strategies or collaborative learning approaches. The study of McQuarrie and McRae (2010) reveal that effective differentiated classrooms are characterized by flexible grouping, allowing students to interact; including those with a comparable readiness level. In accordance with this, Fogarty and Pete (2011) suggest that the teacher should adjust the teaching process according to the learning needs of the students.

Third, invoking a variety in learning activity, to accommodate a diverse way of learning, the teacher should invoke a variety of suitable learning activities. Learning activities were associated significantly with learning outcomes (Bakkenes, Vermunt, \& Wubbels, 2010). In this context teachers opt for a variety of learning activities (Thousand et al., 2007); such as: (1) setting different learning activities that cater for the ability level of students; (2) accept and manage a different learning pace; especially by providing more time for slow learners; and (3) allow learner input as the starting point for learning activities.

Fourth, monitoring individual student needs, here the teacher modifies content, process and product in accordance with the learner's need (Subban, 2006), as part of the goal of DI is to monitor the student needs and support the growth of each child (Hall, Strangman, \& Meyer, 2014; Thousand et al., 2007). Critical teachers imply assessing and monitoring individual student needs. A clear insight in the readiness level of learners is helpful. This is a basic condition to allow teachers to adapt their teaching and support that affect the other DIdimensions.

Fifth, pursuing optimal learning outcomes, the major purpose of $\mathrm{Di}$ is to pursue maximum growth in each student and to pursue the optimum learning outcomes (Hall et al., 2014; Thousand et al., 2007). Pursuing generic learning outcomes is difficult when working with a heterogeneous classroom group. While considering the potential of every student, teachers should put forward the highest outcome level for each student. This might imply adapting assessment tasks to the ability level of the student, considering different benchmark criteria for different students and building on different levels of prior knowledge.

DI implementation is promising, however it is challenging. Tomlinson, Moon, and Callahan (1998) investigated the nature of instructional practices, and evaluated the degree to which teachers respond appropriately to academic diversity. They revealed that few teachers take into account student interest, individual learning profiles or cultural differences when they plan lessons. Most teachers expressed frustration when attempting to deal with learner variety, with many choosing the one-size-fits-all approach to teaching.

Worldwide there is a continuous call for studies presenting evidence about the nature and efficacy of DI-approaches. Such research is -to our knowledge- not available in the Indonesian setting. Therefore, the present study aims at developing a baseline about five DIdimensions practices in Indonesian primary schools by focusing on the following two research questions:

1. What is the extent of DI-implementation in Indonesian primary schools? 
2. What is the nature of DI-adoption in Indonesian primary schools?

\section{Method}

\subsection{Population and research sample}

The population consists of teachers in Grade A level accredited schools in six regions in Jakarta. According to Board of National Accreditation (BANSM, 2014), in 2014, 1522 Schools hold a grade A level accreditation. Teachers from 145 BANSM schools (about 10\% of the schools) were involved in the present study. Schools were chosen randomly, taking into account the number and size of the schools in each region, and respecting an equal balance between public and private schools. This quota sampling method (Kerlinger \& Lee, 2000) resulted in a sample of 604 teachers.

\subsection{Research instruments}

To pursue the research questions, two research instruments were developed: DIImplementation Scale (DIIS), and vignette-based research instrument. The DIIS was developed to determine the extent of DI-implementation. DIIS consists of 15 items; three for each DIdimension to measure the extent to which teachers currently adopt this particular DI-element. The overall reliability of the DIIS is very high (.916 Cronbach Alpha).

The vignette-based instrument was developed to get the teacher perceptions about the nature of DI-adoption. Vignettes are short scenarios or stories in written or pictorial form which participants can comment upon. Vignettes provide a valuable technique for exploring people perception, belief and meanings about specific situation (Barter \& Renold, 1999). The vignettes in this research instrument were based on real life cases/stories derived from Indonesian school reality. Each of the 5 cases addressed a different DI-dimension. The instrument was -after its initial development in English- translated into Indonesian language -Bahasa-Indonesiafollowing the forward-backward translation method (Behling \& Law, 2000). A pilot version of the instrument was presented to a seven teachers from three different primary school teachers -not in the sample- to get their feedback as to clarity and linkage with Indonesian school reality. Each vignette case was followed by three open-ended questions to be answered by the respondent. Teachers were invited to give, next to their ideas, a minimal number of examples, challenges, strategies, actions, etc. The example of the vignette can be found in appendix.

\subsection{Research procedure}

In view of the present large-scale research, permission was first obtained from the authorities of Jakarta. Building on the sampling procedure, every single school was contacted by the researcher. In each school, an introductory session was set up about the focus of the study. Next, teachers were invited to fill out the surveys. Each individual teacher signed an informed consent form. The survey was taken place during March-June 2014.

\subsection{Analysis method}

Quantitative analysis of the DIIS was carried out using statistical software SPSS (Version22). Qualitative analysis was adopted to analyse the vignette responses. This analysis 
followed the three-step approach as described by Miles and Huberman (1994). First, data reduction while reading and reviewing the vignette responses to become familiar with the data. This helped developing a code list. Coding focused on identifying themes in teacher responses in relation to each DI-dimension. Second, coding data were summarized as a table and scores and percentage were calculated. Third, we analysed the data focusing on the proportional distribution of the themes identified.

As vignettes invoked responses to open questions, teacher reactions vary in nature and in number. Some teachers gave a single response, others multiple responses. Hence, when aggregating data, the total number of responses is larger than the sum of teachers. In order to measure the reliability of vignette coding, $15 \%$ of the vignette responses was recoded independently. An acceptable reliability level was observed $($ Kappa $=.87)$.

\section{Results and discussion}

To determine the extent of DI Implementation, teachers were asked to indicate on a scale from 0 to 10 the extent to which they adopt each DI-dimension. Table 2 summarizes the results. No clear benchmark is available to state whether the implementation of a particular DIdimension is high or low. Building on the international discussion about benchmarks in relation to teacher competences, we put forward the value of $80 \%$ (score 8 ) as a critical benchmark. This value reflects the established criteria for Mastery Learning (Zimmerman \& Dibenedetto, 2008).

Table 2: DI implementation and comparison with the benchmark $(\mathrm{N}=604)$

\begin{tabular}{lrrr}
\hline DI dimension & Mean & \multicolumn{1}{c}{ SD } & \multicolumn{1}{c}{$t$} \\
\hline Coping with student diversity & 7,01 & 1,41 & $-17,20^{* * *}$ \\
Adopting specific teaching strategy & 7,49 & 1,27 & $-9,81^{* * *}$ \\
Invoking a variety in learning activity & 7,24 & 1,32 & $-14,06^{* * *}$ \\
Monitoring individual student needs & 7,88 & 1,08 & $-2,65^{* * *}$ \\
Pursuing optimal learning outcomes & 6,91 & 1,76 & $-15,25^{* * *}$ \\
\hline Average DI implementation score & 7,31 & 1,11 & $-15,40^{* * *}$ \\
\hline$* * * p<.001$ & & &
\end{tabular}

Compared to the $80 \%$ benchmark, the data show that the DI-adoption is below threshold for each of the five DI-dimensions. The overall average DI-mean is 7.31. This is also significantly below threshold. The highest mean score is observed in relation to dimension 4, and the lowest mean on dimension 5. This finding corroborate the urgency of increasing of DIimplementation by Indonesian teachers.

The score for DI-dimension 4, monitoring individual student needs, almost reaches the benchmark. This suggests there is hope for change. This is also reflected in the most recent Human Development Index (HDI) data from UNDP (2015) that reflect a gradual improvement of HDI of Indonesia as compared to earlier years (2012: rank 124; 2013: rank 121; 2014: rank 108, 2015: rank 110). 
The score for dimension 5, pursuing optimal learning outcomes, is in line with data from international research (PISA, 2012; TLC, 2014). These data put Indonesia in the lower ranking of educational quality. This urges policy makers to improve the educational quality in Indonesia. As discussed in the introduction, this could be done by improving the quality of teaching related strategies (Maulana et al., 2011; Zulfikar, 2009). The present research results also stress the importance of increasing DI-implementation.

Related to the second research question, we analyse the data for each DI-dimension separately. We present the three most frequently observed themes reflected in teacher responses to questions about each DI-dimension. Although theoretically we use five dimensions to assess DI-adoption, the response from the teacher in several dimensions looks somewhat intertwined between one and other dimension.

Dimension 1: coping with student diversity

Table 3: Dimension 1

$$
\frac{1: \text { Is coping with student diversity realistic? Why? }}{\text { Realistic }=97 \%}
$$

Teachers want students to succeed

Teachers are willing to do extra effort for students

Teachers use appropriate teaching method

Use appropriate teaching method 2: How to cope with student diversity?

Do extra effort \& extra time for students

From the data, we derive that most of the teachers feel realistic about coping with student diversity. Teachers seem to realize their responsibility as to their students. This is in line with the guidelines of Fogarty and Pete (2011); Tomlinson (1995) who revealed that teachers should vary and adapt in relation to individual and diverse students in the classroom. A large proportion of teachers argue they want their students to succeed, and they are willing to make extra efforts for students by using appropriate teaching strategy.

As to the question how teachers cope with student diversity, the three most frequent responses are: teachers use an appropriate teaching strategy, teachers make extra efforts, and devote more time to work with these students, and teacher identify the specific needs and characteristics of these students. These three elements -more or less- fit the study of Hattie (2009); McQuarrie and McRae (2010). They stress that using an appropriate teaching strategy is a positive response to learner diversity. McQuarrie and McRae (2010) stress the most effective strategy is flexible grouping. Furthermore, they also reveal that to address the student diversity, requires time, training, intentional planning and long-term commitment. In our findings, the willingness of teachers to give extra effort and devote extra time is relevant. In terms of identifying student characteristics, Fogarty and Pete (2011) suggest using "it's all about me" cards. The student writes on the card their readiness, interest, and learning profile. 
Related to question three, Brazdeikis and Masaitis (2012) emphasize the use of computer teaching aids and methods promoting the transformation of educational environments into personal learning environments. The latter implies that the learning environment respects students' individual learning objectives, skills, needs and experience. In terms of parental support, several studies show that parent involvement in children's learning is a major source for children's academic achievement (Grolnick, Raftery-Helmer, \& Flamm, 2013; Hattie, 2009; Hill \& Tyson, 2009). Parental aspirations are positively related to student motivation (Fan, Williams, \& Wolters, 2012). However, parents should also get involved without an emphasis on control, punishment and/or pressure. The latter has proven to be negatively associated to academic success (Karbach, Gottschling, Spengler, Hegewald, \& Spinath, 2013). Regarding school support, our findings can be connected to the meta-analysis study Hattie (2009) who reported that principal and school leader involvement have a positive impact on student achievement. In addition, Rodriguez (2012) also stressed that teachers need support from the principal in view of dealing with diversity.

\section{Dimension 2: adopting specific teaching strategy}

Table 4: Dimension 2

\begin{tabular}{lr}
\hline \multicolumn{1}{c}{ 1: What teaching strategies do you adopt to cope with student diversity? } & $29 \%$ \\
Grouping the student & $27 \%$ \\
Interactive learning & $11 \%$ \\
Experiential learning & \\
& 2: Do you agree with the "one-size-fits-all" strategy? Why? \\
$\quad$ Agree $=6 \%$, not agree $=94 \%$ & $71 \%$ \\
Not agree, because teachers want to accommodate students diversity & $16 \%$ \\
Not agree, because one strategy is not enough & $7 \%$ \\
Not agree, because teachers want to achieve the goal of learning &
\end{tabular}

The data show most teachers adopt grouping strategies, opt for interactive learning strategies, and/or apply experiential learning strategies. This finding is aligned with the studies of McQuarrie and McRae (2010) that reveal the benefit of grouping students. However Schofield (2013) warned that ability grouping could undermine the achievement of initially low-achieving students, thus even increasing the achievement gap.

The results show an emphasis on interactive and experiential learning. In terms of interactive learning and experiential learning, Hannafin, Hill, and Land (1997) show that learning is most effective when it evolves from rich hands-on concrete experiences, building on realistic and relevant problems. Furthermore, Freeman and Dobbie (2005) revealed that interactive learning, made the learning more fun, more attentive, and allowed them to learn more than in traditional lecture formats. However, with regard to interactivity, interactive features of a learning environments should not only elicit active processing of learning contents but also focus attention to central concepts and their interrelations, and central principles and their application in problem solving (Renkl \& Atkinson, 2007).

Our research also shows most teachers do not agree with the one-size-fits-all (OSFA) strategy. Most state that they want to accommodate student diversity. This fits the recommendation of Fogarty and Pete (2011); Fox and Hoffman (2011) to drop the OSFA 
strategy in teaching. The finding shows that -at least in theory- teachers acknowledge the disadvantages of OSFA, and shown their willingness to accommodate student diversity.

\section{Dimension 3: invoking a variety in learning activity}

Table 5: Dimension 3 1: What learning activities do you invoke in students?

Activity that uses teaching aids

Personal/group task

2: Why do you invoke these specific learning activities?

To activate students in class

To help students to comprehend the lesson

Students like that activity

\section{3: Do you agree with selecting different activities for different students? Why? Agree $=61 \%$, not agree $=39 \%$}

Agree, because to cope with students diversity

Typical activities invoked by teachers comprise: learning activities that imply the use of teaching aids, learning through playing/games, and personal/group task assignment. Reasons for selecting these vary; to activate students in the class, to help students comprehend the lesson, and/or because students like/prefer this learning activity.

As discussed above, Brazdeikis and Masaitis (2012) state that teaching aids can promote the transformation of educational environments into a "personal" learning environment. In terms of invoking play/games activities, Hattie (2009) shows in his meta-analysis that these are positively related to student achievement. Regarding giving students particular tasks, Papaioannou and Kouli (1999) point out that lessons comprising explicit task allocations to students result in higher student self-confidence, and lower somatic anxiety. Certain authors nevertheless point out that the nature of task allocation is critical. Learning tasks that are too strictly regulated, imply external control and invoke memorization, do not result in higher learning benefits. In contrast, task should be related to authentic contexts and invoke dynamic learning (Iran-Nejad, 1995).

Other teacher responses stress the need for planning different activities for different students. Most teachers agree with this idea since it guarantees engaging all students in learning at the same time. Certain teachers do explicitly not agree with this idea. They stress this can cause disruption in the class.

\section{Dimension 4: monitoring individual student needs}

Table 6: Dimension 4

\section{1: Is it realistic to monitor all student needs? Why?}

\section{Realistic $=94 \%$}

It is part of a teacher's responsibility 


\begin{tabular}{lr}
\hline \multicolumn{1}{c}{$2:$ What are your actions to monitor student needs? } \\
Try to understand the student characteristics and needs & $27 \%$ \\
Give extra time for guidance & $22 \%$ \\
Teach students according to their characteristics & $15 \%$ \\
3: What are the problems when attempting to monitor student needs? & $26 \%$ \\
Lack of parent attention & $22 \%$ \\
Lack of student motivation & $19 \%$ \\
Lack of teaching aids & \\
\hline
\end{tabular}

The data shows that most teachers feel realistic about the possibility to monitor student needs. They state it is part of a teacher's responsibility, and even necessary, and they will do the best for their students. These reiterate the statements put forward in relation to dimension 1 .

Actions to monitor student needs comprise: to understand student characteristics and needs, to provide extra time for guidance, and to teach according to student characteristics. It seems teachers really want the best for their students. In term of understanding the student needs and characteristic, these results confirm finding of Fogarty and Pete (2011) who recommend teachers to identify particular student needs and characteristics. Regarding the guidance and attention for students, Pas and Newman (2013) state that to improve student achievement, particular teacher support interventions need to be implemented while taking enough time within school days and throughout the school year.

Teacher mention problems related to the lack of parental support, the lack of student motivation, and the lack of teaching aids. This reiterates themes stated in dimension 1 about parent involvement linking parent engagement to academic achievement (Fan et al., 2012; Grolnick et al., 2013; Hattie, 2009; Hill \& Tyson, 2009; Karbach et al., 2013). Furthermore, student motivation is considered being crucial for learning in a DI setting. Student motivation is known to be positively related to student achievement (Hattie, 2009).

Teaching aids reappear in the discussion about DI-dimension 2 and 4. The research of Rodriguez (2012) reports in this context that schools should provide teachers with sufficient support as to this theme (i.e., availability of materials, professional development opportunities, computers, Internet).

Dimension 5: pursuing optimal learning outcomes.

Table 7: Dimension 5

1: What action will you do to pursue the optimal learning outcomes with money from "Jakarta Smart" program?

Recommend the student to buy teaching aids \& learning facilities $58 \%$

$\begin{array}{ll}\text { Improve teacher professionalism } & 16 \%\end{array}$

$\begin{array}{ll}\text { Motivate students } & 10 \%\end{array}$

2: Regardless of the "Jakarta Smart" money, how do you pursue optimal learning outcomes?

Opt for fun and active learning activities $28 \%$

$\begin{array}{ll}\text { Motivate the student } & 22 \%\end{array}$

Give extra time for remedial \& enrichment activities $20 \%$

Lack of parental support

$\begin{array}{ll}\text { 3: What are the problems to pursue optimal learning outcomes? } & 36 \%\end{array}$

$\begin{array}{ll}\text { Lack of student motivation } & 32 \%\end{array}$

Lack of teaching aids

$9 \%$


Since December 2012, The Governor of Jakarta has implemented the "Jakarta Smart" program (Beritajakarta, 2012). The program gives extra money to particular students to cater for their learning expenses. This particular vignette also invites teachers to indicate what they do in order to pursue optimal learning outcomes. The vignette data show most teachers recommend the students to invest in teaching aids and extra learning facilities. This reflects teachers' beliefs about teaching aids and learning facilities. It is striking this reappears in relation to most DI-dimensions.

Regardless of the "Jakarta Smart" money, actions to pursue optimal learning outcomes comprise: choosing fun and active learning activities, motivating students, and providing extra time for remedial and enriching instructional activities. Active learning, according to Schank (1994), is crucial to empower students to try, retry, test new behaviour that might help to attain better results. Auster and Wylie (2006) stress that active engagement is at the heart of children's acquisition of knowledge. Furthermore, they emphasize that it creates a more dynamic classroom atmosphere: students buzzing with anticipation at the start of the class, eagerly waving their hands in the air during class discussion, building on each other's ideas towards new levels of understanding, and remaining in their seats when class time ends.

Teachers repeat the importance of high student motivation. Ames (1992) stresses that teacher enhance student motivation by stressing the importance of effort and to commitment. However, Meece, Anderman, and Anderman (2006) warn for a too stressing focus on high ability and grades. In contrast, they suggest emphasizing mastery, understanding, and improving skills and knowledge.

Regarding extra time for remedial and enrichment activities, Guarino, Villarico, and Laud (2013) revealed that enrichment programs clearly resulted -pre to post test- score increases. Additionally, there is the advantage it encourages all learners to be the best, to meet problems, to build on their strengths, to be realistic in their self-appraisal, to help in seeking appropriate transition behaviour, to empower learner, as well as to push learners to be successful. In contrast, the remedial approaches are often criticized. Jeffreys (2014) mentions the risk it isolates weaker, borderline, or failing students. This authors suggests to adopt remediation only when needed. In general, our data also show teachers try to build up a strong relationship with their students. The latter, according to Hattie (2009), is known to have a positive impact on student achievement.

As to the problems observed when pursuing optimal learning outcomes, teachers mention the lack of parental support, the lack of student motivation, and the lack of teaching aids. These are very similar to what was mentioned in dimension 4.

\section{General discussion and conclusions}

Our first finding builds on DIIS data. The data reveal an overall DI-implementation level of 7.31. Although this could be interpreted as relatively high, this is significantly below the benchmark as compared to mastery learning criteria (80\%). Moreover, none of the DI- 
dimensions benchmarks is at par with the standard. Little empirical research is available that looks at DI-benchmarks elsewhere. Most research focuses on particular local initiatives to deal with diversity. The research by Wilujeng (2012) in Indonesia revealed that adopting different types of instruction will accommodate the different learning styles of student. However, it seems a tedious task if implemented in a big class and this will be a challenge for the teacher.

Another research on implementing DI by Tobin and Tippett (2014) revealed that teacher face the possibilities and potential barriers. The possibilities are; DI provided a framework for teaching, planning, and reflecting on practice, student appeared more involved in learning, DI provided multiple representation of content, and called for teacher to be facilitator of learning instead of dispenser information. The barriers are; teachers experienced fears and insecurities related to the new expectation about their performance, the lack of time, curricular and assessment demand, and lack of resources. Another study studying teacher education showed incongruent results (Valcke, Struyven, \& Rots, 2012). These researchers identified a strong reported emphasis on student diversity during pre-service education. But this was in particular true for kindergarten and primary school teachers; and less available in junior and senior high school teachers. However, a further qualitative analysis showed that practical skills to cope with DI were less developed and that innovation competences of future teachers were weakly pursued and weakly developed. Student teachers were convinced that DI was important, but were not well prepared to tackle DI.

The findings in the Indonesian setting have key implications at policy level; in particular, when it comes to the professional development of in-service teachers, next to reconsidering the curriculum for pre-service teachers. However, the lesson on professional development should be matched to the teaching reality, as in some respects, there is a mismatch between the lessons of university instruction and the real contexts of the classrooms where many Indonesian teachers work (Luschei \& Zubaidah, 2012).

Secondly, our findings help looking at the "nature" of DI-adoption by Indonesian primary school teachers. Teacher responses to the vignettes show a clear awareness of the importance of DI and the fact that student diversity should be considered during instruction. In relation to dimension 1, coping with student diversity, most of the teachers have realized the diversity of their students, and they want to cope with it by looking for appropriate teaching strategies. In view of dimension 2, adopting specific teaching strategy, most of the teachers report the adoption of grouping strategies. Most teachers do not agree with OSFA strategy, and want to accommodate to student diversity. Reacting to dimension 3, invoking a variety of learning activity, most teachers are willing to use teaching aids and play/games to motivate students and making them more active. Considering dimension 4, monitoring individual student needs, most teachers feel realistic about monitoring individual needs, and feel responsible. Regarding to dimension 5, pursuing optimal learning outcome, most teachers recommend students to buy teaching aids/learning support. In view of most DI-dimensions, teachers mention a lack of parental support, the lack of student motivation, and the lack of teaching aids.

It is also important to indicate that teachers in the present study remained very general and even abstract in the way they talk about student diversity and the way to implement DI. It is somewhat striking that teachers hardly mention very concrete strategies that are known to be effective in a DI setting, such as peer tutoring, student tutoring, student tracking programs, 
direct instruction, etc. Though teachers were explicitly invited to give examples of their own instructional strategies, teacher input remained rather vague and general. This introduces some limitations of the present study.

Despite the fact our results build on the input from a large-scale sample, the present study reflects limitations. Firstly, the study builds on survey data. Teachers "talk" about DI and the way they cope with student diversity. The question is to what extent teachers "walk the talk"? Future studies could complement the current findings with information from other stakeholders; e.g., students, parents, educational authorities. Also, the findings could be compared to factual data resulting from observation studies. This reflects the approach adopted by e.g., Lucero, Valcke, and Schellens (2013) in the Ecuadorian setting, who compared reported inquiry teaching approaches and student centred techniques of primary school teachers with data resulting from video analysis of actual classroom teaching. They found conflicting results between the "talk" and the way teacher actually carry out their instruction. Second, the vignettes reflected particular concrete situations that might have differed from the teacher's own reality; thus neglecting their own professional behaviour in their on setting. This calls for other research strategies that invite teachers to discuss their own classroom reality and how they cope with their student diversity. Thirdly, the current study did not develop an inventory of concrete instructional approaches of teachers, did not collect ways to develop an in-depth understanding of student diversity (instruments, lesson plan, observation checklists, interviews, focus group discussions), and did not develop an overview of materials currently used by teachers to be distributed within the professional community. Future research could build on the "community of learners" idea to invoke this kind of exchange of strategies, instruments, and materials.

The quality of education in Indonesia -currently at a low level-can clearly be improved. Although the present research shows teachers recognize student diversity and try to cope with it, they still have problems implementing DI. This calls for central policies to push the professional development of in-service teachers. The Ministry of Education should pay more attention to the teacher professional development. For instance -but in a developed country context- the Belgian Ministry of Education changed the law on teacher education and required all teacher education curricula to play explicit attention to teacher competences that cater for student diversity, coping with student heterogeneity in urban settings, and problems related to multilingual and multicultural settings. Other countries such as Korea (Cha \& Ahn, 2014), Canada (McQuarrie \& McRae, 2010), England and Australia (Mills et al., 2014) also emphasize professional standards that cater for DI. Central policies should also launch comprehensive professional development plans involving in-service teachers. These plans could build on a school-based exchange of good practices, school-based lesson plan studies focusing on DIsolutions, collegial consultation when attempting to implement DI.

Our findings also suggest adopting school policies that put DI at the centre of its focus. This could e.g., increase parental involvement. In the Indonesian context this could start from the "Jakarta Smart" program to support parents in developing a personal learning environment for their children at home (acquisition of tools at home, such as reference materials, calculators, books, stationaries). School policies could centre on helping learners outside the classroom before and after school time- to support homework, language upgrading activities, computer 
clubs, book reading activities, science clubs. The latter could additionally influence student motivation.

Worldwide, student diversity and related differentiated instruction is on the agenda of policy makers, schools, and teachers. The present study can be considered as a first benchmark study for the Indonesian context. Nevertheless, more research is needed to look at solutions for teachers and learners- that fit the particular Indonesian context.

\section{Acknowledgments}

This study was supported by Lotus Erasmus Mundus Action 2 project, funded by the European Commission (ref.nr. Agreement Number: 2011-2584/001-001-EM Action2Partnerships).

\section{References}

Ames, C. (1992). Classrooms: goals, structures, and student motivation. Journal of educational psychology, 84(3), 261. doi:10.1037/0022-0663.84.3.261

Auster, E. R., \& Wylie, K. K. (2006). Creating active learning in the classroom: a systematic approach. Journal of management education, 30(2), 333-353. doi:10.1177/1052562905283346

Bakkenes, I., Vermunt, J. D., \& Wubbels, T. (2010). Teacher learning in the context of educational innovation: Learning activities and learning outcomes of experienced teachers. Learning and Instruction, 20(6), 533-548. doi:10.1016/j.learninstruc.2009.09.001

BANSM. (2014). Schools in Indonesia (data set). Retrieved 1 Feb 2014 from http://www.ban-sm.or.id/.

Barter, C., \& Renold, E. (1999). The use of vignettes in qualitative research. Social research update, 25, 1-5. doi:10.3171/jns.2000.93.1.0033

Behling, O., \& Law, K. S. (2000). Translating Questionnaires and Other Research Instruments: Problems and Solutions. Thousand Oaks, CA: Sage Publications Inc. doi:10.4135/9781412986373

Beloshitskii, A. V., \& Dushkin, A. V. (2005). An experiment in differentiated insruction in a higher technical education institution. Russian education and society, 47(9), 54-61. doi:10.1080/10609393.2005.11056996

Beritajakarta. (2012). Peluncuran Kartu Jakarta Pintar [The Launching of Jakarta Smart Card]. Retrieved 20 Feb 2014 from http://beritajakarta.com/potret/album/549/Peluncuran_Kartu_Jakarta_Pintar.

Brazdeikis, V., \& Masaitis, M. (2012). Teaching aids in teaching and learning environments of lithuanian schools. Social Sciences, 76(2), 74-83. doi:10.5755/j01.ss.76.2.1964

Cha, H. J., \& Ahn, M. L. (2014). Development of design guidelines for tools to promote differentiated instruction in classroom teaching. Asia Pacific Education Review, 15(4), 511-523. doi:10.1007/s12564014-9337-6

Chamberlin, M., \& Power, R. (2010). The promise of differentiated instruction for enhacing the mathematical understandings of college students. Teaching mathematic and its application, 29(3), 113-139. doi:10.1093/teamat/hrq006

Dalhouse, D. W., Risko, V. J., Esworthy, C., Grasley, E., Kaisler, G., McIlvain, D., \& Stephan, M. (2009 ). Crossing boundaries and initiating conversation about RTI: understanding and applying differentiated classroom instruction. The reading teacher, 63(1), 84-87. doi:10.1598/RT.63.1.9

Fan, W., Williams, C. M., \& Wolters, C. A. (2012). Parental involvement in predicting school motivation: similar and differential effects across ethnic groups. The journal of educational research, 105(1), 21-35. doi:10.1080/00220671.2010.515625 
Firmender, J. M., Reis, S. M., \& Sweeny, S. M. (2013). Reading comprehension and fluency levels ranges across diverse classrooms: the need or differentiated reading insruction and content. Gifted Child Quarterly, 57(I), 3-14. doi:10.1177/0016986212460084

Fogarty, J. R., \& Pete, M. B. (2011). Supporting Differentiated Instruction; A Professional Learning Communities Approach. Bloomington, NJ: Solution Tree Press.

Fox, J., \& Hoffman, W. (2011). The Differentiated Instruction Book of Lists. San Francisco: Jossey-Bass.

Freeman, J., \& Dobbie, A. (2005). Use of audience response system to augment interactive learning. Family medicine, 37(1), 12-14.

Grimes, K. J., \& Stevens, D. D. (2009). Glass, bug, mud. Phi delta kappan, 90(9), 677-680. doi:10.1177/003172170909000914

Grolnick, W. S., Raftery-Helmer, J. N., \& Flamm, E. S. (2013). Parent involment in learning. In Hattie, J. and Anderman, E.M. (Eds). International Guide to Student Achievement. (pp. 101-103). NY: Routledge.

Guarino, A. T., Villarico, G. M. D., \& Laud, G. M. O. (2013). The effectiveness of the enrichment program among Brokenshire College first year student nurses. Southeast asian interdisciplinary research journal, 1(1), 45-58.

Hall, T., Strangman, N., \& Meyer, A. (2014). Differentiated instruction and implication for UDL implementation. Effective classroom practices report. National center on accessing the general curriculum. Retrieved 1 February 2015 from http://aim.cast.org/sites/aim.cast.org/files/DI_UDL 10.6.14_0.docx.

Hannafin, M. J., Hill, J. R., \& Land, S. M. (1997). Student-centered learning and interactive multimedia: status, issues, and implication. Contemporary Education, 68(2), 94-99.

Hattie, J. (2009). Visible Learning: A Synthesis of Over 800 Meta-analyses Relating to Achievement. New York: Routledge.

Heacox, D. (2012). Differentiating instruction in the regular classroom. Minneapolis: Free Spirit Publishing.

Hill, N. E., \& Tyson, D. F. (2009). Parental involvement in middle school: a meta-analytic assessment of the strategies that promote achievement. Developmental psychology, 45(3), 740-763. doi:10.1037/a0015362

Iran-Nejad, A. (1995). Constructivism as substitute for memorization in learning: meaning is created by learner. Education, 116(1), 16.

Johnsen, S. (2003). Adapting instruction with heterogenous groups. Gifted Child Today, 26(3), 5-6. doi:10.1177/107621750302600302

Karbach, J., Gottschling, J., Spengler, M., Hegewald, K., \& Spinath, F. M. (2013). Parental involvement and general cognitive ability as predictors of domain-specific academic achievement in early adolescence. Learning and Instruction, 23, 43-51. doi:10.1016/j.learninstruc.2012.09.004

Kerlinger, F. N., \& Lee, H. B. (2000). Foundations of Behavioral Research. Orlando: Harcourt College Publisher.

Levine, M. (2002). A Mind at a Time. New York: Simon \& Schuster.

Lucero, M., Valcke, M., \& Schellens, T. (2013). Teachers' beliefs and self-reported use of inquiry in science education in public primary schools. International journal of science education, 35(8), 1407-1423. doi:10.1080/09500693.2012.704430

Luschei, T. F., \& Zubaidah, I. (2012). Teacher training and transitions in rural Indonesian schools: a case study of Bogor, West Java. Asia Pacific Journal of Education, 32(3), 333-350. doi:10.1080/02188791.2012.711241

Maulana, R., Opdenakker, M. C., den Brok, P., \& Bosker, R. (2011). Teacher-student interpersonal relationships in Indonesia: profiles and importance to student motivation. Asia Pacific Journal of Education, 31(01), 33-49. doi:10.1080/02188791.2011.544061

McQuarrie, L. M., \& McRae, P. (2010). A provincial perspective on differentiated instruction: the alberta initiative for school improvement (AISI). Journal of applied research on learning, 3(4), 1-18.

Meece, J. L., Anderman, E. M., \& Anderman, L. H. (2006). Classroom goal structure, student motivation, and academic achievement. Annu. Rev. Psychol, 57, 487-503. doi:10.1146/annurev.psych.56.091103.070258

Miles, M. B., \& Huberman, A. M. (1994). Qualitative Data Analysis: an Expanded Sourcebook. California: Sage Publication.

Mills, M., Monk, s., Keddiea, A., Renshawa, P., Christiec, P., Geelanb, D., \& Gowletta, C. (2014). Differentiated learning: from policy to classroom. Oxford review of education, 40(3), 331-348. doi:10.1080/03054985.2014.911725

Papaioannou, A., \& Kouli, O. (1999). The effect of task structure, perceived motivational climate and goal orientations on students' task involvement and anxiety. Journal of Applied Sport Psychology, 11(1), 5171. doi:10.1080/10413209908402950 
Pas, E. T., \& Newman, D. S. (2013). Teacher mentoring, choacing, and consultation. In Hattie, J. and Anderman, E. M. (Eds.). International Guide to Student Achievement. (pp. 152-154). NY: Routledge.

PISA. (2012). PISA 2012 result. Retrieved 1 November 2014 from http://www.oecd.org/pisa/keyfindings/pisa2012-results.htm.

Renkl, A., \& Atkinson, R. K. (2007). Interactive learning environments: contemporary issues and trends. an introduction to special issue. Educational psychology review, 19(3), 235-238. doi:10.1007/s10648-0079052-5

Rodriguez, A. (2012). An analysis of Elementary School Teachers' Knowledge and Use of Differentiated Instruction. Unpublished Ed.D. Dissertation. Illinois. Olivet Nazarene University.

Schank, R. C. (1994). Active learning through multimedia. IEEE multimedia, 1(1), 69-78.

Schofield, J. W. (2013). Ability grouping. in Hattie, J. and Anderman, E.M. (Eds). International Guide to Student Achievement. (pp.212-214). NY: Routledge.

Sofo, F., Fitzgerald, R., \& Jawas, U. (2012). Instructional leadership in Indonesian school reform: overcoming the problems to move forward. School Leadership \& Management, 32(5), 503-522. doi:10.1080/13632434.2012.723616

Subban, P. (2006). Differentiated instruction: a research basis. International Education Journal, 7(7), 935-947.

Thousand, J. S., Villa, R. A., \& Nevin, A. I. (2007). Differentiating Instruction: Collaborative Planning and Teaching for Universally Designed Learning. Thousand Oaks, CA: Corwin Press.

TLC. (2014). The Learning Curve Report, Retrieved 2 December 2014 from http://thelearningcurve.pearson.com/.

Tobin, R., \& McInnes, A. (2008). Accommodating differences: variations in differentiated litearcy instruction in grade 2/3 classroom. Literarcy, 42(1), 3-9. doi:10.1111/j.1467-9345.2008.00470.x

Tobin, R., \& Tippett, C. D. (2014). Possibilities and potential barriers: Learning to plan for differentiated instruction in elementary science. International Journal of Science and Mathematics Education, 12(2), 423-443. doi:10.1007/s10763-013-9414-z

Tomlinson. (1995). Deciding to differentiate instruction in the middle school: one school's journey. Gifted Child Quarterly, 39(2), 77-114. doi:10.1177/001698629503900204

Tomlinson, \& Imbeau, M. (2010). Leading and managing a differentiated classroom. Alexandria, Virginia: ASCD.

Tomlinson, Moon, T. R., \& Callahan, C. M. (1998). How well we addressing academic diversity in the middle school? Middle school journal, 29(3), 3-11.

Tulbure, C. (2011). Differentiated instruction for pre-service teachers: an experimental investigation. Procedia social and behavioral sciences, 30, 448-452. doi:10.1016/j.sbspro.2011.10.088

UNDP. (2015). Human Development Report, Retrieved 17 March 2016 from http://hdr.undp.org/sites/default/files/hdr_2015_statistical_annex.pdf.

Valcke, M., Struyven, K., \& Rots, I. (2012). Als het krijtstof neerdaalt... een bijdrage aan de beleidsevaluatie van de lerarenopleiding in vlanderen. [EVALO: a contribution to the evaluation of teacher education in Flanders]. Gent, Brussels: Gent university, Free University Brussels.

Waxman, H. C., Alford, B. L., \& Brown, D. B. (2013). Individualized instruction. In Hattie, J. and Anderman, E. M. (Eds.). International Guide to Student Achievement. (pp. 405-407). NY: Routledge.

Wilujeng, N. C. S. (2012). The differentiated instruction and its implementation for developing countries: Partnership students learning Indonesian language in bridging course program. Journal of Education, $5(\mathrm{I}), 49-52$.

Zimmerman, B. J., \& Dibenedetto, M. K. (2008). Mastery learning and assessment: implications for students and teachers in an area of high-stakes testing. Psychology in the schools, 45(3), 206-216. doi:10.1002/pits.20291

Zulfikar, T. (2009). The making of Indonesia education: An overview on empowering Indonesian teachers. Journal of Indonesian Social Sciences and Humanities, 2, 13-39. 
Appendix; Example of vignette

Case $* 1$



in the class room with 40 students, Dewi, a grsde 6 teacher, reblly wants to tesch her students with her best effort she csn do. She notices that sll students have s diverse badkground, such $\mathrm{s}$ in ability, learning styles, and soocosconomic status. With thet kind of student diversity, she hes to deliver the lessons enacted by school policy. Dewi really wants all grade 6 students to pass the notional exsminstion.

\section{Questions:}

1. Is Dewi's ambition realiatic? Why

2. Whst is your suggestion for Dewi to cope with student diversity?

Suggestion 1:

Suggestion 2:

3. What kind of support should Dewi receive to cope with student diversity? Support 1:

Support 2: 